\title{
Growth and Yield Response of Soyabean (Glycine max Merr.) to Organic and Inorganic Fertilizer in Edo Rainforest of Nigeria
}

\author{
Ehizogie Joyce Falodun', James Osaretin Ehigiator ${ }^{2 *}$, Sunday Aghafekokhian Ogedegbe1 \\ ${ }^{1}$ Department of Crop Science, Faculty of Agriculture, University of Benin, Benin City, Nigeria \\ ${ }^{2}$ Department of Soil Science, Faculty of Agriculture, University of Benin, Benin City, Nigeria \\ Email: *ehizogie.falodun@uniben.edu
}

Received 25 November 2015; accepted 27 December 2015; published 30 December 2015

Copyright (C) 2015 by authors and Scientific Research Publishing Inc.

This work is licensed under the Creative Commons Attribution International License (CC BY). http://creativecommons.org/licenses/by/4.0/

(c) (i) Open Access

\section{Abstract}

In tropical and subtropical areas, the importance of organic manure and inorganic fertilizer in increasing crop production for food security cannot be overemphasized. A field study was therefore conducted at the Department of Crop Science, University of Benin Teaching and Research Farm, Benin City, Edo State during the 2012/2013 cropping seasons, to investigate the effects of poultry manure and inorganic NPK 15:15:15 fertilizer on the growth and yield of soya bean (Glycine max (L.) Merr). The experiment was laid out as a randomized complete block design (RCBD) in three replications with six treatments viz: $0,200 \mathrm{~kg} / \mathrm{ha} N P K$ 15:15:15, $10 \mathrm{t} / \mathrm{ha}$ poultry manure, $7 \mathrm{t} / \mathrm{ha}$ poultry manure $+60 \mathrm{~kg} / \mathrm{ha} \mathrm{NPK} 15: 15: 15,5 \mathrm{t} / \mathrm{h}$ a poultry manure $+100 \mathrm{~kg} / \mathrm{ha} \mathrm{NPK} 15: 15: 15,2.5$ t/ha poultry manure $+150 \mathrm{~kg} / \mathrm{ha}$ NPK 15:15:15. Parameters on vegetative and reproductive traits were taken on five randomly selected plants. Results showed that plant height, number of branches and number of leaves per plant were enhanced by organic and inorganic fertilizers. Similarly, combined application of organic and inorganic fertilizer increased the pod weight/plant compared to the sole application of organic and inorganic fertilizer. Application rate of $2.5 \mathrm{t} / \mathrm{ha}$ poultry manure +150 $\mathrm{kg} / \mathrm{ha}$ NPK 15:15:15 gave the highest grain yield of 7.367 t/ha followed by $5 \mathrm{t} / \mathrm{ha}$ poultry manure + $100 \mathrm{~kg} / \mathrm{ha} \mathrm{NPK}$ which gave $(7.244 \mathrm{t} / \mathrm{ha})$, application rate of $7 \mathrm{t} / \mathrm{ha}$ poultry manure $+60 \mathrm{~kg} / \mathrm{ha} \mathrm{NPK}$ gave (6.654 t/ha), while $10 \mathrm{t} / \mathrm{ha}$ poultry manure gave $(3.889 \mathrm{t} / \mathrm{ha})$ and this was followed by application rate of $200 \mathrm{~kg} / \mathrm{ha}$ NPK 15:15:15 which gave (4.112 t/ha) and the control gave the lowest grain yield of $(3.245 \mathrm{t} / \mathrm{ha})$. The application of $2.5 \mathrm{t} / \mathrm{ha}$ poultry manure $+150 \mathrm{~kg} / \mathrm{ha} \mathrm{NPK} 15: 15: 15$ is therefore suggested for the growth and yield of soyabean in Edo rainforest of Nigeria.

\footnotetext{
*Corresponding author.
}

How to cite this paper: Falodun, E.J., Ehigiator, J.O. and Ogedegbe, S.A. (2015) Growth and Yield Response of Soyabean (Glycine max Merr.) to Organic and Inorganic Fertilizer in Edo Rainforest of Nigeria. American Journal of Plant Sciences, 6, 3293-3297. http://dx.doi.org/10.4236/ajps.2015.619321 
Keywords

Soyabeans, Poultry Manure, Yield, Grain, NPK Fertilizer

\section{Introduction}

The use of fertilizer is one of the most important factors to increase crop yield in soya bean production. Phosphorus is an important element which application is necessary for growth, development and yield of soya beans [1]. Reasonable yield and profit can be obtained from the production of soyabean if farmers concern themselves with the various ways in which growth and yield of the crop can be enhanced. One of these ways is to consider the nutrient requirement of the crop. This is important because of the depletion of nutrients in the soil caused by continuous cropping. [2] suggested that for continuous use of land for crop production, organic and inorganic fertilizers must be incorporated into the soil as this will provide multiple benefits for improving the chemical and physical status of the soil as well as improve yield of soya bean.

[3] showed that adding compost to the soil along with fertilizer application will result in increased crop yield. [4] worked on the effect of packaged organic and inorganic fertilizers on the growth and yield of soya bean. The study showed that moderate rates of NPK 15:15:15 fertilizer (100 or $200 \mathrm{~kg} / \mathrm{ha}$ ) can be applied to boost soya bean production. Similarly, low levels of packaged organic fertilizer can be applied as plants responded well to these levels in the experiment reported.

Application of mineral fertilizer as soil fertility management under intensive continuous cropping is no longer feasible due to non availability, high cost where available and the numerous side effects on the soil [5]. Farmers using mineral fertilizer for years usually notice signs of soil exhaustion shown by sick appearance of the plant, leaf discolorations, retarded growth and low yield. A combined use of both organic and inorganic fertilizer is beneficial. Research has shown that adding organic manure along with mineral fertilizer will result in increase crop yield [3]. [6] evaluated the effect of fertilizer on the grain yield of soya bean. He reported that nutrients in inorganic fertilizers are readily available for soya bean plant uptake upon application while the organic forms of nutrient are slowly available.

The objective of this study therefore is to examine the effect of organic and inorganic fertilizers on the agronomic performance of soya bean with a view to determining their optimum level for the crop.

\section{Materials and Methods}

A field experiment was conducted at the Department of Crop Science, University of Benin Teaching and Research Farm (latitude $6^{\circ} 19 \mathrm{~N}$, longitude $5^{\circ} 37 \mathrm{E}$ ) in Benin-City, Rain Forest of Edo State, Nigeria. The portion of land for the experiment was overgrown with spear grass (Imperata cylindrica) and elephant grass (Pennisetum purpereum) before the experiment.

\subsection{Source of Planting Materials and Fertilizers}

The variety of soya bean TGX 1440 was obtained from Institute of Agricultural Research and Training (IAR and T) Ibadan. The inorganic fertilizer (NPK 15:15:15) which is commercially available was procured from Agricultural Development Programme (ADP) Benin. Poultry manure was collected from University of Benin Farm project and was analysed for physical and chemical composition (Table 1). Composite soil samples were taken randomly from the site at a depth of 0 - $20 \mathrm{~cm}$ using soil auger prior to planting for analysis of physio-chemical properties. The soil samples were air dried and crushed to pass through a $2 \mathrm{~mm}$ sieve prior to analysis. The soil $\mathrm{pH}$ was determined with the use of a glass electrode in a 1:1 ratio of soil for water suspension. Organic carbon was determined by wet oxidation method as modified by [7]. Total nitrogen was obtained by macro kjeldahl method as modified by [7]. Available P was determined by Bray I method [8] and P was estimated by the blue colour method of [9]. Exchangeable $\mathrm{K}$ and $\mathrm{Na}$ was determined with flame photometer while $\mathrm{Ca}$ and $\mathrm{Mg}$ was determined using the atomic absorption spectrophotometer (Table 1).

\subsection{Experimental Design}

The experiment was laid out as randomized complete block design (RCBD) with three replications. Each replicate 
Table 1. Physical and chemical properties of poultry manure and soil of the experimental site pre plant and post harvest.

\begin{tabular}{|c|c|c|c|}
\hline \multirow{2}{*}{ Soil properties } & \multicolumn{2}{|c|}{ Experimental site } & \multirow{2}{*}{ Poultry manure } \\
\hline & Pre & Post & \\
\hline $\mathrm{pH}\left(\mathrm{H}_{2} \mathrm{O}\right)$ & 4.54 & 5.10 & 6.40 \\
\hline Organic carbon $\left(\mathrm{g} 100 \mathrm{~g}^{-1}\right)$ & 0.40 & 0.65 & 23.00 \\
\hline Total N $\left(\mathrm{g} 100 \mathrm{~g}^{-1}\right)$ & 0.05 & 0.03 & 2.13 \\
\hline Total P $\left(\mathrm{mg} \cdot \mathrm{kg}^{-1}\right)$ & 18.9 & 12.7 & 4.30 \\
\hline $\mathrm{K}\left(\mathrm{cmol} \cdot \mathrm{kg}^{-1}\right)$ & 0.19 & 0.14 & 1.12 \\
\hline $\mathrm{Ca}\left(\mathrm{cmol} \cdot \mathrm{kg}^{-1}\right)$ & 1.15 & 0.81 & 3.76 \\
\hline $\mathrm{Mg}\left(\mathrm{cmol} \cdot \mathrm{kg}^{-1}\right)$ & 0.76 & 0.56 & - \\
\hline $\operatorname{Mn}\left(\mathrm{cmol} \cdot \mathrm{kg}^{-1}\right)$ & - & - & 1.14 \\
\hline $\mathrm{Zn}\left(\mathrm{cmol} \cdot \mathrm{kg}^{-1}\right)$ & - & - & 0.13 \\
\hline $\mathrm{Fe}\left(\mathrm{cmol} \cdot \mathrm{kg}^{-1}\right)$ & - & - & 3.27 \\
\hline $\mathrm{Na}\left(\mathrm{cmol} \cdot \mathrm{kg}^{-1}\right)$ & - & - & 0.17 \\
\hline Sand $\left(\mathrm{g} \cdot \mathrm{kg}^{-1}\right)$ & 752.1 & 756.0 & - \\
\hline Clay $\left(g \cdot \mathrm{kg}^{-1}\right)$ & 198.0 & 163.4 & - \\
\hline Silt $\left(g \cdot \mathrm{kg}^{-1}\right)$ & 46.0 & 48.2 & - \\
\hline Textural class & Sandy & loam & - \\
\hline
\end{tabular}

was separated from each other by $1 \mathrm{~m}$ pathway for ease of agronomic operations. Each of the replicates consisted of 6 plots giving a total of 18 plots of individual sizes $1.2 \times 3 \mathrm{~m}\left(3.6 \mathrm{~m}^{2}\right)$. The treatments were an unfertilized control, $200 \mathrm{~kg} /$ ha NPK 15:15:15, 10 t/ha poultry manure, 7 t/ha poultry manure + $60 \mathrm{~kg} / \mathrm{ha}$ NPK 15:15:15, 5 t/ha poultry manure $+100 \mathrm{~kg} / \mathrm{ha}$ NPK 15:15:15 and 2.5 t/ha poultry manure $+150 \mathrm{~kg} / \mathrm{ha}$ NPK 15:15:15. These treatments were assigned to each experimental unit using the table of random numbers.

\subsection{Cultural Practices}

Two seeds were planted per stand at a depth of $5 \mathrm{~cm}$ and spaced at $60 \mathrm{~cm}$ between rows and $15 \mathrm{~cm}$ within row. Plants were thinned to 1 seedling per stand 2 weeks after planting. Weeding was done manually at 3, 8 and 12 weeks after sowing. Two weeks before planting, poultry manure was incorporated into the soil and the inorganic NPK 15:15:15 fertilizer was applied based on the treatment.

\subsection{Data Collection}

Parameters on 5 randomly selected plants taken at 9 weeks after sowing were plant height (cm); number of leaves per plant and number of branches. At harvest, number of pods /plant, weight of pods/plant (g), weight of grains (g)/plant and grain yield (kg/ha) were computed.

The data collected were subjected to statistical analysis of variance (ANOVA) using GENSTAT and significant differences among treatment means separated using least significant differences (LSD).

\section{Result}

There was increase in plant height per plant of soya beans in response to the organic and inorganic fertilizer treatments when compared with the control. Application rate of 2.5 t/ha PM and $150 \mathrm{~kg} / \mathrm{ha}$ NPK gave the highest plant height $(70.9 \mathrm{~cm})$. The minimum plant height of $(46.0 \mathrm{~cm})$ was observed with the control. The effect of fertilizer application was not significant on the number of branches and leaves (Table 2). The effect of fertilizer application on number of pods, pod weight, grain weight/plot (g/ha) and grain yield t/ha was significant among the treatments at 5\% level of probability in the experiment. The number of pods, weight of pod, grain weight and yield increased with combined application of organic and inorganic fertilizers compared to sole application 
of either NPK or poultry manure. Applying 2.5 t/ha poultry fertilizer in combination with $150 \mathrm{~kg} / \mathrm{ha}$ NPK enhanced grain yield $(7.367 \mathrm{t} / \mathrm{ha}$ ) of soya bean better than other treatments though not significantly different from plants treated with 7 t/ha poultry manure $+60 \mathrm{~kg} / \mathrm{ha}$ NPK (6.656 t/ha) and $5 \mathrm{t} / \mathrm{ha}$ poultry manure $+100 \mathrm{~kg} / \mathrm{ha}$ NPK (7.244 t/ha). However, significantly different from sole applications of $200 \mathrm{~kg} / \mathrm{ha}$ NPK and $10 \mathrm{t} / \mathrm{ha}$ poultry manure which gave (3.889 t/ha) and (4.112 t/ha) respectively. The control recorded the lowest value for grain yield (3.244 t/ha) and for all other reproductive characters measured (Table 3).

\section{Discussion}

The significant increase in plant height observed by plants treated with fertilizer may be attributed to internodes elongation and other nutrients received by the plant from both organic and inorganic sources. This observation confirms the findings of [6] who reported that nutrients in inorganic are readily available for plant up take upon application while the organic forms of nutrients are slowly available. The increase in the number of pods, pod weight and yield with the application rate of $2.5 \mathrm{t} /$ ha poultry $+150 \mathrm{~kg} / \mathrm{ha}$ NPK could be due to the rate of release of nutrients which were much higher in the inorganic fertilizers since they provided major elements at the early stage of plant growth and development. Thus, plants showed accerlerated growth and organic manure in combination complements this effect at the later stage of growth. The effect of the nutrients in increasing growth and yield of onion was relatively higher when in association with one another. [10] stated that combine application of organic and inorganic fertilizer gave better results than their sole application in onion production, they emphasized that high and sustainable crop yield can be obtained with judicious use of combine application. This observation is in agreement with the work of [11] who recorded an improvement in yield of onion and also in the soil physical and chemical properties when organic manure was applied in combination with inorganic ferti-

Table 2. Effect of fertilizer application on the growth of soya bean (Glycine max).

\begin{tabular}{cccc}
\hline Treatment & Plant height $(\mathrm{cm})$ & Number of branches & Number of leaves \\
\hline Control & 46.0 & 23.60 & 92.00 \\
$200 \mathrm{~kg} / \mathrm{ha} \mathrm{NPK}$ & 55.7 & 37.00 & 100.00 \\
$10 \mathrm{t} / \mathrm{ha}$ poultry manure & 60.0 & 39.00 & 94.00 \\
7 t/ha poultry manure + $60 \mathrm{~kg} / \mathrm{ha} \mathrm{NPK}$ & 50.7 & 30.00 & 110.00 \\
5 t/ha poultry manure + $100 \mathrm{~kg} / \mathrm{ha} \mathrm{NPK}$ & 51.0 & 33.30 & 112.00 \\
2.5 t/ha poultry manure + $150 \mathrm{~kg} / \mathrm{ha} \mathrm{NPK}$ & 65.9 & 30.30 & 142.70 \\
Mean & 55.7 & 33.86 & Ns \\
LSD $(P<0.05)$ & 13.29 & Ns \\
\hline
\end{tabular}

Table 3. Effects of fertilizer application on number of pods, weight of pods, weight of grains and grain yield of soya bean (Glycine max).

\begin{tabular}{|c|c|c|c|c|}
\hline Treatment & No. of pods/plant & Wt. of pods (g)/plant & Wt. of grains (g)/plant & Grain yield (t/ha) \\
\hline Control & 130.00 & 21.50 & 29.20 & 3.244 \\
\hline 200 kg/ha NPK & 171.00 & 28.50 & 37.00 & 4.112 \\
\hline 10 t/ha poultry manure & 132.00 & 25.20 & 35.00 & 3.889 \\
\hline $7 \mathrm{t} / \mathrm{ha}$ poultry manure $+60 \mathrm{~kg} / \mathrm{ha} \mathrm{NPK}$ & 190.00 & 53.50 & 59.90 & 6.656 \\
\hline 5 t/ha poultry manure $+100 \mathrm{~kg} / \mathrm{ha} \mathrm{NPK}$ & 225.00 & 54.50 & 65.20 & 7.244 \\
\hline $2.5 \mathrm{t} / \mathrm{ha}$ poultry manure $+150 \mathrm{~kg} / \mathrm{ha} \mathrm{NPK}$ & 322.00 & 85.80 & 66.30 & 7.367 \\
\hline Mean & 195.00 & 44.80 & 48.80 & 5.41 \\
\hline $\operatorname{LSD}(P<0.05)$ & 99.8 & 30.67 & 5.53 & 2.15 \\
\hline
\end{tabular}


lizer. The quick response to combine use of fertilizer by soyabean plant may be due to the fact that mineral fertilizers mineralized quickly, releases its nutrients to crop faster and eventually leached beyond the root zone of crops and organic manure in combination complements this effect by exerting their effect for a longer periods compared to sole application of these fertilizer thereby resulting in better crop growth and yield of the crop. The control plot produced the lowest values for grain yield of soyabean, due to the absence of adequate nutrient level which is an important factor needed for proper growth and development of every plant including soyabean and so the plants had to depend on the inherent soil nutrient which was low.

\section{Conclusion}

From this study, it was observed that the use of organic and inorganic fertilizer at different levels increased the yield of soya bean. However, application rate of $2.5 \mathrm{t} / \mathrm{ha}$ poultry $+150 \mathrm{~kg} / \mathrm{ha}$ NPK gave better results compared to the other treatments.

\section{References}

[1] Kakar, K.M., Taria, M., Taj, F.H. and Nawab, K. (2002) Phosphorus Use Efficiency as Affected by Phosphorus Application and Inoculation. Pakistan Journal of Agronomy, 1, 49-50. http://dx.doi.org/10.3923/ja.2002.49.50

[2] Basso, B. and Rictchie, J.T. (2005) Impact of Compost Manure and Inorganic Fertilizer on Nitrate Leaching and Yield for a 6-Year Maize-Alfalfa Rotation in Midnignan. Agriculture, Ecosystems and Environment, 108, 309-341. http://dx.doi.org/10.1016/j.agee.2005.01.011

[3] Akanbi, W.B. (2002) Growth, Nutrient Uptake and Yield of Maize and Okra as Influenced by Compost and Nitrogen Fertilizer under Different Cropping Systems. Ph.D. Thesis, University of Ibadan, Ibadan.

[4] Falodun, E.J., Osaigbovo, A.U. and Remison, S.U. (2010) The Effect of Packaged Organic and Inorganic Fertilizer on the Growth and Yield of Soya Bean (Glycine max). African Journal of General Agriculture, 6.

[5] Akindede, E.A. and Okeleye (2005) Short and Long Term Effects of Sparingly Soluble Phosphates on Crop Production in Two Contrasting Alfisols. In: Danso, S.K.A. and Abekoa, M.K., Eds., West African Journal of Applied Ecology, 8,141-149.

[6] Espinoza, L. (2001) Effect of Fertilizer on Grain Yield of Soya Bean. European Journal of Agronomy, 13, $212-221$.

[7] Jackson, M.L. (1969) Soil Chemical Analysis. Constable and Co Ltd., London, 132 p.

[8] Bray, R.H. and Kurtz, L.T. (1945) Determination of Total Organic and Available Forms of P in Soils. Soil Science, 59, 39-45. http://dx.doi.org/10.1097/00010694-194501000-00006

[9] Murphy, J. and Riley, J.P. (1962) Modified. Single Solution Methods for Determination of Phosphorus in Natural Water. Analytical Chemistry Acta, 27, 31-36. http://dx.doi.org/10.1016/S0003-2670(00)88444-5

[10] Bayu, W., Rethman, N.F.G., Hammes, P.S. and Alemu, G. (2006) Effects of Farmyard Manure and Inorganic Fertilizer on Sorghum Growth, Yield and Nitrogen Use in a Semi-Arid Area of Ethopia. Journal of Plant Nutrition, 29, 391-407. http://dx.doi.org/10.1080/01904160500320962

[11] Arisha, H.M.E., Gad, A.A. and Younes, S.E. (2003) Response of Some Pepper Cultivars to Organic and Mineral Nitrogen Fertilizer under Sandy Soil Conditions. Zagazig Journal of Agricultural Research, 30, 1875-1899. 